\title{
PENGARUH MOTIVASI KERJA TERHADAP KINERJA GURU RADHATUL ATFAL DI KOTA PEKALONGAN
}

\author{
Slamet Riyadi, Aria Mulyapradana \\ Politeknik Pusmanu Pekalongan
}

\begin{abstract}
This study aims to examine the effect of work motivation on the performance of teachers Radhatul Atfal in Pekalongan City. This research was conducted on teachers as many as 97 people by using data collection method by census method. Data analysis technique used is validity test with matrix component, reliabilias test with alfha cronbach, regression analysis, $t$ test and $r 2$ test with adjusted $r$ square. The results showed that directly influenced work motivation postive and significant influence on performance.
\end{abstract}

Keywords: Work motivation, performance, teacher

\begin{abstract}
ABSTRAK
Penelitian ini bertujuan untuk meneliti pengaruh motivasi kerja terhadap kinerja guru Radhatul Atfal di Kota Pekalongan. Penelitian ini dilakukan terhadap guru sebanyak 97 orang dengan menggunakan cara pengumpulan data dengan metode sensus. Teknik analisi data yang digunakan adalah uji validitas dengan component matrik, uji reliabilias dengan alfha cronbach, analisis regresi, uji $t$ dan uji $r^{2}$ dengan adjusted $r$ square. Hasil penelitian menunjukkan bahwa secara langsung dipengaruh motivasi kerja berpengaruh postif dan signifikan terhadap kinerja.
\end{abstract}

Kata kunci : Motivasi kerja, kinerja, guru

\section{PENDAHULUAN}

Pendidikan merupakan hal yang sangat penting bagi masa depan, baik masa depan bangsa secara makro maupun masa depan anak didik secara mikro. Dengan pendidikan yang layak dan berkualitas maka bangsa ini akan bisa maju dan berkembang serta dapat bersaing dengan bangsa lain. Pendidikan (UU No. 20 Tahun 2003 tentang Sistem Pendidikan Nasional) adalah usaha sadar dan terencana untuk mewujudkan suasana belajar dan proses pembelajaran agar peserta didik secara aktif mengembangkan potensi dirinya untuk memiliki kekuatan spiritual keagamaan, akhlak mulia, keterampilan yang diperlukan dirinya, masyarakat, bangsa dan negara.

Hal senada, berdasarkan Undang-undang Republik Indonesia No. 20 Tahun 2003 bahwa Pendidikan Nasional berfungsi mengembangkan kemampuan dan membentuk watak serta peradaban bangsa yang bermartabat dalam rangka mencerdaskan kehidupan bangsa, bertujuan untuk berkembangnya potensi peserta didik agar menjadi manusia yang beriman dan bertakwa kepada Tuhan Yang Maha Esa, berakhlak mulia, sehat, berilmu, cakap, kreatif, mandiri, dan menjadi warga negara yang demokratis serta bertanggung jawab. Oleh karena itu, peningkatan mutu pendidikan merupakan sasaran pembangunan di bidang pendidikan nasional 
dan merupakan bagian integral dari upaya peningkatan kualitas manusia Indonesia secara menyeluruh.

Peningkatan mutu pendidikan pada setiap jenjang dan satuan pendidikan merupakan hal yang penting. Berbagai upaya usaha telah dilakukan untuk meningkatkan mutu pendidikan nasional, misalnya pengembangan kurikulum nasional dan lokal, peningkatan kompetensi guru melalui pelatihan, pengadaan buku dan alat pembelajaran, pengadaan dan berbaikan sarana dan prasarana pendidikan dan meningkatkan manajemen sekolah.

Guru merupakan garda terdepan dalam dunia pendidikan dan salah satu komponen yang menempati posisi sentral dan sangat strategis dalam sistem pendidikan. Guru merupakan faktor yang dominan dalam kaitannya dengan peningkatan mutu pendidikan karena bagian yang tidak terpisahkan dari sistem pendidikan secara keseluruhan yang terlibat langsung dalam proses belajar mengajar. Guru bermutu atau tidak bermutu dapat dilihat dari profesionalitas guru itu sendiri. Profesionalitas seorang guru tercermin dari layak tidaknya guru dalam mengajar. Sehubungan dengan itu, perlu dilakukan peningkatan kualitas kinerja guru dalam mengembangkan mutu pendidikan dan pembelajaran.

Oleh karena itu, guru merupakan sumber daya manusia sangat penting artinya didalam menentukan kelangsungan hidup suatu instansi pendidikan dan selalu diperhatikan agar kelancaran jalannya institusi pendidikan lebih terjamin dan semakin meningkat. Tenaga pengajar (Guru) merupakan bagian yang integral dari suatu perkumpulan faktor-faktor produksi dan memegang peranan penting dibandingkian faktor-faktor lainnya. Mengingat sedemikian pentingnya faktor tenaga pengajar, maka institusi harus merekrut karyawan yang berkompeten yaitu mempunyai kemampuan bekerja dan kemampuan berorganisasi yang baik. Disamping itu harus memberikan tunjangan kesejahteraan kepada tenaga pengajar (guru) agar lebih bersemangat dalam menjalankan tugas-tugasnya di instansi pendidikan.

Dalam rangka peningkatan kualitas kinerja guru maka pemerintah mengembangkan program sertifikasi pendidik yaitu suatu program yang bertujuan untuk menilai profesionalisme pendidik guna menentukan kualitas pendidik dalam melaksanakan tugas. Seperti yang tertuang dalam Undang-undang Republik Indonesia No. 14 tahun 2005 tentang Guru dan Dosen dijelaskan bahwa guru wajib memiliki kualifikasi akademik, kompetensi, sertifikat pendidik, sehat jasmani dan rohani serta memiliki kemampuan untuk mewujudkan tujuan pendidikan nasional. Oleh karena itu, guru harus memenuhi sejumlah persyarartan yang ada untuk membuktikan bahwa mereka telah menjadi tenaga profesional termasuk syarat pemenuhan kompetensi pendidik sehingga kinerja guru dapat dipengaruhi seberapa besar guru menguasai kompetensi yang harus dipenuhinya.

Kinerja suatu instansi pendidikan tergantung pada tenaga pengajar (guru) Namun atasan dapat berperan dalam merencanakan, melaksanakan dan mengendalikan suatu instansi yang di pimpin. Hal ini, atasan harus mempunyai peran penting dalam usahanya untuk memotivasi dan mengelola karyawannya. Mangkunegara (2009) mengatakan bahwa kinerja berasal dari kata job performance (prestasi kerja atau prestasi sesungguhnya yang dicapai oleh seseorang). Senada dengan Martinis Yamin dan Maisah (2010) kinerja guru adalah perilaku atau respon yang memberikan hasil yang mengacu kepada apa yang mereka kerjakan dalam menghadapi tugas. Selain itu, kinerja juga dapat diartikan sebagai hasil pencapaian guru dalam melaksanakan tugas yang didasarkan kecakapan, pengalaman, waktu, output yang dihasilkan yang tercemin baik dari kualitas maupun kuantitasnya. 
Tinggi rendahnya kinerja tenaga pengajar (guru) berkaitan erat dengan sistem pemberian penghargaan yang diterapkan oleh instansi pendidikan tempat mereka bekerja. Pemberian penghargaan yang tidak tepat dapat berpengaruh terhadap peningkatan kinerja seseorang. Setiap instansi tidak hanya memberikan gaji pokok tetapi juga memberikan jaminan kesejahteraan bagi karyawannya yang sering disebut tunjangan kesejahteraan. Jika tunjangan kesejahteraan yang diberikan tenaga pengajar (guru) dirasa dapat bermanfaat maka hal itu akan membuat mereka lebih termotivasi untuk bekerja lebih maksimal dann optimal sehingga tidak menutup kemungkinan bagi mereka untuk menjadi karyawan atau tenaga pengajar (guru) yang berprestasi maka memudahkan tercapainya tujuan organisasi.

Raudatul Atfal atau disingkat RA merupakan jenjang pendidikan anak usai dini (PAUD) dibawah pengelolaan Kementerian Agama, RA setara dengan taman kanakkanak (TK) dimana kurikulumnya ditekankan pada pemberian rangsangan pendidikan untuk membantu pertumbuhan dan perkembangan jasmani dan rohani anak, agar anak memiliki kemampuan mental dan spiritual yang baik. Jenjang pendidikan RA atau TK merupakan jenjang pendidikan yang sangat penting dalam proses perkembangan siswa didiknya dikarenakan pada jenjang ini siswa didik berada dalam masa golden age yakni usia 0-5 tahun dimana dalam masa ini merupakan masa emas anak untuk mengoptimalkan pertumbuhan dan perkembangnya serta pembentukan sistem saraf secara mendasar sudah terjadi. Di masa lima tahun pertama usai anak adalah masa kritis sehingga masa ini merupakan masa yang menjadi basis, landasan dan fondasi berbagai aspek perkembangan anak. Oleh karena itu guru-guru RA memiliki tugas dan tanggung jawab yang sangat penting dalam meningkatkan mutu pendidikan dan kualitas anak didiknya. Disamping itu guru dituntut untuk memberikan pelayanan yang prima dan berkualitas kepada anak didiknya.

Dengan tuntutan tersebut tenaga pengajar (guru) harus memiliki kinerja yang baik dan optimal hal tersebut tidak sebanding dengan pemberian gaji guru sebagai contoh masih sedikitnya guru RA yang memiliki sertifikasi guru dan ada guru yang mendapatkan upah gaji dibawah Upah Minimun Kota (UMK) hal tersebut menjadi salah satu akibat adanya penurunan kinerja guru. Dan masih banyak lagi faktor yang mempengaruhi kinerja guru antara lain kemampuan dalam penguasaan materi bahan ajar, kemampuan dalam berkomunikasi yang baik, lingkungan, komitmen dalam bertugas dan kemampuan dalam memanfaatkan media pembelajaran.

Dengan melihat faktor-faktor kinerja tersebut akan mempengaruhi motivasi kerja. Motivasi kerja yang dimiliki setiap guru berbeda-beda antara satu dengan yang lain. Padahal motivasi kerja sangat diperlukan bagi guru dalam melaksanakan tugastugasnya sebagai pendidik guna meningkatkan keberhasilan dalam proses pembelajaran. Melihat fenomena tersebut maka penelitian ini peneliti ini mengetahui faktor motivasi kerja yang mempengaruhi kinerja Guru RA di Kota Pekalongan.

\section{TINJAUAN PUSTAKA}

\subsection{Motivasi Kerja}

\subsubsection{Pengertian Motivasi}

Menurut Winardi (2002) motivasi kerja adalah suatu kekuatan potensial yang ada dalam diri seorang manusia, yang dapat dikembangkan oleh sejumlah kekuatan luar yang pada intinya berkisar sekitar imbalan moneter, dan imbalan non moneter yang dapat mempengaruhi hasil kinerjanya secara positif atau secara negatif, hal ini tergantung pada situasi dan kondisi yang dihadapi orang yang bersangkutan. 
2.1.2 Faktor-Faktor yang mempengaruhi Motivasi Kerja

Faktor-faktor yang mempengaruhi motivasi kerja seseorang dalam melaksanakan pekerjaan dipengaruhi oleh beberapa faktor baik faktor intrenal/ intrinsik yang berasal dari proses psikologis dalam diri seseoran maupun dari diri faktor eksternal/ ekstrinsik yang berasal dari luar diri seseorang.

Herzberg (Jhon M. Ivancevich, 2006) mengembangkan teori isi yang dikenal sebagai teori motivasi dua faktor. Kedua faktor tersebut disebut dissatisfier-satisfier, motivasi higiene atau faktor-faktor intrinsik dan ekstrinsik. Faktor-faktor tersebut diantranya faktor instrinsik/ satifier antara lain : pencapaian, pengakuan, tanggung jawab, pekerjaan itu sendiri, keinginan untuk tumbuh

Sedangkan faktor-faktor yang mempengaruhi motivasi kerja yang berasal dari ekstrinsik/ dissatisfier antara lain : Gaji, keamanan pekerjaan, kondisi kerja, status, prosedur perusahaan, kualitas pengawasan teknis, kualitas hubungan interpersonal.

2.1.3 Jenis-Jenis Motivasi

Jenis-jenis motivasi dapat dikelompokan menjadi dua jenis (Hasibuan, 2014);

a. Motivasi positif, manajer memotivasi bawahan dengan memberikan hadiah kepada mereka yang berprestasi baik. Dengan motivasi positif ini semangat kerja bawahan akan meningkat, karena manusia pada umumnya senang menerima yang baik-baik saja.

b. Motivasi negatif, manajer memotivasi bawahan dengan memberikan hukuman kepada mereka yang pekerjaannya kurang baik (prestasi rendah). Dengan memotivasi negartif ini semangat kerja bawahan dalam waktu pendek akan meningkat karena takut dihukum. Penggunaan kedua motivasi tersebut haruslah diterapkan kepada siapa dan kapan agar dapat berjalan efektif merangsang gairah semangat kerja karyawan dalam bekerja.

2.1.4 Tujuan Motivasi

Motivasi memberikan dampak yang positif bagi pekerja dan bagi perusahaan. Berawal dari adanya motivasi membuat pekerja menjadi semangat dalam bekerja, mau dan mampu melakukan pekerjaanya dengan baik (Hasibuan, 2014).

Manajer atau pimpinan yang berhasil dalam hal memotivasi karyawan seringkali menyediakan suatu lingkungan dimana tujuan-tujuan tepat tersedia untuk memenuhi kebutuhan. Tujuan-tujuan motivasi tersebut antara lain : mendorong gairah dan semangat kerja karyawan, meningkatkan moral dan kepuasan kerja karyawan, meningkatkan produktivitas kerja karyawan, mempertahankan loyalitas dan kestabilitas karyawan perusahaan, meningkatkan kedisiplinan dan menurunkan tingkat absensi karyawan, menciptakan suasana dan hubungan kerja yang baik.

\subsection{Kinerja}

\subsubsection{Pengertian Kinerja}

Kinerja dalam organisasi merupakan jawaban dari berhasil atau tidaknya tujuan organisasi yang telah ditetapkan. Para atasan atau manajer sering tidak memperhatikan kecuali sudah sangat buruk atau segala sesuatu jadi serba salah. Terlalu sering manajer tidak mengetahui betapa 
buruknya kinerja telah merosot sehingga perusahaan / instansi menghadapi krisis yang serius. Kesan-kesan buruk organisasi yang mendalam berakibat dan mengabaikan tanda - tanda peringatan adanya kinerja yang merosot. Mangkunegara (2009) kinerja (prestasi kerja) adalah hasil kerja secara kualitas dan kuantitas yang dicapai oleh seseorang pegawai dalam melaksanakan tugasnya sesuai dengan tanggung jawab yang diberikan kepadanya. Hasibuan (2014) mengemukakan kinerja (prestasi kerja) adalah suatu hasil kerja yang dicapai seseorang dalam melaksanakan tugas tugas yang dibebankan kepadanya yang didasarkan atas kecakapan, pengalaman dan kesungguhan serta waktu.

2.2.2 Faktor-Faktor Yang Mempengaruhi Kinerja

Menurut Prawirosentono (1992) faktor-faktor yang mempengaruhi kinerja karyawan, yaitu :

a. Efektifitas dan efisiensi

Bila suatu tujuan tertentu akhirnya bisa dicapai, kita boleh mengatakan bahwa kegiatan tersebut efektif tetapi apabila akibatakibat yang tidak dicari kegiatan menilai yang penting dari hasil yang dicapai sehingga mengakibatkan kepuasan walaupun efektif dinamakan tidak efesien. Sebaliknya, bila akibat yang dicari-cari tidak penting atau remeh maka kegiatan tersebut efesien.

b. Otoritas (wewenang)

Otoritas menurut adalah sifat dari suatu komunikasi atau perintah dalam suatu organisasi formal yang dimiliki seorang anggota organisasi kepada anggota yang lain untuk melakukan suatu kegiatan kerja sesuai dengan kontribusinya. Perintah tersebut mengatakan apa yang boleh dilakukan dan yang tidak boleh dalam organisasi tersebut

c. Disiplin

Disiplin adalah taat kepda hukum dan peraturan yang berlaku. Jadi, disiplin karyawan adalah kegiatan karyawan yang bersangkutan dalam menghormati perjanjian kerja dengan organisasi dimana dia bekerja.

d. Inisiatif

Inisiatif yaitu berkaitan dengan daya pikir dan kreatifitas dalam membentuk ide untuk merencanakan sesuatu yang berkaitan dengan tujuan organisasi.

2.2.3 Penilaian Kinerja

Berkenaan dengan pentingnya penilaian terhadap kinerja guru. Georgia Departemen of Education telah mengembangkan teacher performance assessment instrument yang kemudian dimodifikasi oleh Depdiknas menjadi Alat Penilaian Kemampuan Guru (APKG). Alat penilaian kemampuan guru, meliputi: (1) rencana pembelajaran (teaching plans and materials) atau disebut dengan RPP (Rencana Pelaksanaan Pembelajaran), (2) prosedur pembelajaran (classroom procedure), dan (3) hubungan antar pribadi (interpersonal skill) (Depdiknas, 2008). Berdasarkan dari berbagai pengertian di atas, kinerja adalah hasil kerja yang dicapai oleh individu atau kelompok dalam suatu organisasi sesuai dengan tanggung jawab yang telah diberikan kepadanya dengan tujuan untuk mencapai tujuan yang telah ditetapkan organisasi tersebut. 
Menurut Peraturan menteri Negara Pendayagunaan Aparatur Negara dan Reformasi Nomor 16 Tahun 2009 dalam Kemendiknas (2010), Penilaian Kinerja Guru (PKG) adalah penilaian dari tiap butir kegiatan tugas utama guru dalam rangka pembinaan karir, kepangkatan, dan jabatannya. Sejalan dengan pengertian di atas turut dibahas mengenai Sistem PKG, "sistem Penilaian Kinerja Guru adalah sistem penilaian yang dirancang untuk mengidentifikasi kemampuan guru dalam melaksanakan tugasnya melalui penguasaan kompetensi yang ditunjukkan dalam unjuk kerjanya.

\subsection{Kerangka Berpikir}

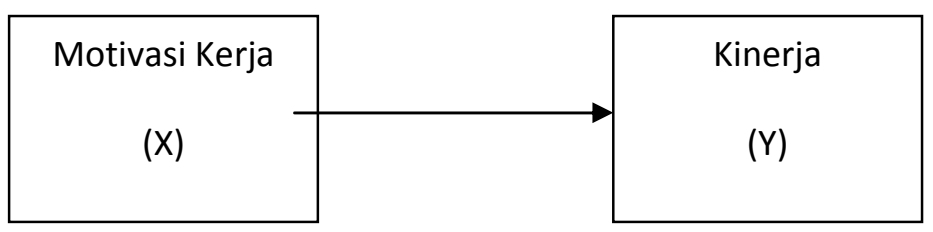

Gambar 2.1 Kerangka Berpikir

\section{METODE PENELITIAN}

Dalam penelitian ini metode analisis yang digunakan yaitu penelitian kuantitatif karena dalam memberikan gambaran atas suatu peristiwan atau gejala, menggunakan alat bantu statistik baik statistik deskriptif maupun statistik inferensial (Kholil, 2006). Sedangkan metode yang digunakan adalah metode sensus, metode ini digunakan untuk mengkaji seluruh populasi. Data yang diperlukan dalam penelitian ini berasal dari jenis data primer yaitu data yang diperoleh secara langsung dari sumbernya. Data hasil isian kuisioner yang didapat dari responden. Populasi dalam penelitian ini adalah seluruh Kepala Sekolah dan Guru Kota Pekalongan sebanyak 97 guru.

Penelitian ini merupakan penelitian empiris yang membuktikan pengaruh variabel motivasi berpengaruh terhadap kinerja pada guru sekolah RA Kota Pekalongan. Variabel yang diteliti dalam penelitian ini adalah variabel dependent $(\mathrm{Y})$ kinerja guru, variabel independent $(\mathrm{X})$ motivasi kerja.

Sumber data dalam penelitian ini adalah subyek dari mana data dapat diperoleh, data ini diperoleh dari penyebaran kuesioner secara langsung kepada para responden dari Kepala Sekolah dan Guru RA Kota Pekalongan. Dalam kuesioner tersebut dibuat skala pengukuran, skala pengukuran yang dipakai untuk melakukan pengukuran indikator kuesioner adalah Skala LIKERT dengan pengukuran sebagai berikut selalu dengan skor (5), sering dengan skor (4), kadang-kadang dengan skor (3), kurang dengan skor (2), tidak pernah dengan skor (1).

\section{HASIL DAN PEMBAHASAN}

\subsection{Hasil Penelitian}

4.1.1 Uji Validasi

Dalam pengujian validitas dibantu dengan program SPSS untuk menentukan apakah kuesioner tersebut sudah valid atau belum. Pengujian validitas menggunakan metode analisis faktor. Analisis faktor digunakan untuk menguji apakah suatu konstruk mempunyai un dimensionalitas atau apakah indikator baik, Untuk mengetahui valid tidaknya suatu variabel yang 
diuji dilakukan dengan membandingkan nilai KMO (Kaiser-Meyer-Olkin) and Bartlett's Test lebih besar dari 0,5. Sedangkan jika component matrix atau loading factor-nya lebih besar dari 0,4 berarti valid dan jika lebih kecil item dari variabel yang diuji berarti tidak valid. Berdasarkan hasil perhitungan validitas pada setiap item pernyataan hasil yang diperoleh sebagai berikut:

Tabel. 4.1 (Kaiser Meiser Olkin Measure of Sampling Adequacy) dan Loading Factor Hasil Analisis Faktor

\begin{tabular}{c|c|c|c|c} 
Variabel & KMO & Indikator & $\begin{array}{c}\text { Loading } \\
\text { Faktor }\end{array}$ & Ket \\
\hline Motivasi & \multirow{2}{*}{0.773} & $\mathrm{X} 1.1$ & 0.661 & Valid \\
$(\mathrm{X} 1)$ & & $\mathrm{X} 1.2$ & 0.624 & Valid \\
& & $\mathrm{X} 1.3$ & 0,729 & Valid \\
& & $\mathrm{X} 1.4$ & 0,664 & Valid \\
& & $\mathrm{X} 1.5$ & 0,620 & Valid \\
& & $\mathrm{X} 1.6$ & 0,541 & Valid \\
& & $\mathrm{X} 1.7$ & 0,404 & Valid \\
& & $\mathrm{X} 1.8$ & 0,503 & Valid \\
& & $\mathrm{X} 1.9$ & 0,671 & Valid \\
& & $\mathrm{X} 1.10$ & 0,454 & Valid
\end{tabular}

\begin{tabular}{c|c|c|c|c} 
Variabel & KMO & Indikator & $\begin{array}{c}\text { Loading } \\
\text { Faktor }\end{array}$ & Ket \\
\hline $\begin{array}{c}\text { Kinerja } \\
\text { (Y) }\end{array}$ & 0,824 & Y.1 & 0,813 & Valid \\
& & Y.2 & 0,746 & Valid \\
& & Y.3 & 0,796 & Valid \\
& & Y.4 & 0,812 & Valid \\
& & Y.5 & 0,649 & Valid \\
& & Y.6 & 0,616 & Valid \\
& & Y.7 & 0,595 & Valid \\
& & Y.8 & 0,636 & Valid \\
& & Y.9 & 0,604 & Valid \\
& & Y.10 & 0,571 & Valid \\
& & Y.11 & 0,632 & Valid \\
& & Y.12 & 0,541 & Valid \\
& & Y.13 & 0,598 & Valid \\
& & Y.14 & 0,495 & Valid
\end{tabular}

Berdasarkan tabel di atas diketahui bahwa semua nilai $\mathrm{KMO}>0,5$ yaitu untuk variabel motivasi $(X)$ sebesar 0,773 ; variabel kinerja $(Y)$ sebesar 0,824 . Semua nilai KMO lebih besar 0,5, yang berarti bahwa sampel memenuhi syarat minimal measure sampling adequacy (kecukupan pengukuran sampel). Sedangkan dilihat dari semua indikator diatas memiliki nilai loading factor > 0,4 yang berarti semua item pertanyaan dari seluruh instrumen penelitiann (kuesioner) adalah valid. 


\subsubsection{Uji Reliabilitas}

Suatu konstruk atau variabel dikatakan reliabel jika memberikan nilai Cronbach Alpha > 0,7. Hasil uji reliabilitas dapat dilihat sebagai berikut:

Tabel. 4.2 Hasil Uji Reliabilitas

\begin{tabular}{c|l|c|c|c} 
Variabel & \multicolumn{1}{|c|}{$\begin{array}{c}\text { Nama } \\
\text { Variabel }\end{array}$} & $\begin{array}{c}\text { Cronbach } \\
\text { Alpha }\end{array}$ & $\begin{array}{c}\text { Nilai Alpha } \\
\text { Standar }\end{array}$ & Keterangan \\
\hline $\mathrm{X}$ & Motivasi $(\mathrm{X})$ & 0,786 & 0,7 & Reliabel \\
\hline $\mathrm{Y}$ & Kinerja $(\mathrm{Y})$ & 0,897 & 0,7 & Reliabel
\end{tabular}

Berdasarkan hasil pengujian reliabilitas diperoleh hasil dengan semua nilai Cronbach Alpha masing-masing variabel lebih besar dari nilai 0,7. Jadi dapat dinyatakan bahwa motivasi (X), kinerja (Y) yang digunakan dapat menghasilkan data yang reliabel atau dapat dipercaya.

4.1.3 Uji Normalitas

Dalam penelitian ini, untuk menguji normalitas digunakan uji statistik non-parametrik Kolmogorof-Smirnov (K-S)

Tabel 4.3 Uji Normalitas

One-Sample Kolmogorov-Smirnov Test

\begin{tabular}{|ll|r|}
\hline & & $\begin{array}{c}\text { Unstandardized } \\
\text { Residual }\end{array}$ \\
\hline $\mathrm{N}$ & Mean & 97 \\
Normal & .0000000 \\
Parameters, & Std. & .31038682 \\
& Deviatio & \\
& $\mathrm{n}$ & \\
Most & Absolute & .059 \\
Extreme & Positive & .048 \\
Differences & Negative & -.059 \\
Kolmogorov-Smirnov Z & .581 \\
Asymp. Sig. (2-tailed) & .889 \\
\hline
\end{tabular}

a. Test distribution is Normal.

b. Calculated from data.

Dari tabel di atas diperoleh nilai asymp sig $=0,889>0,05$ artinya data berdistribusi normal.

4.1.4 Uji Asumsi Klasik

Uji Heteroskedastisitas dilakukan dengan menggunakan uji Glejser, yang dilakukan dengan meregresikan nilai absolut residual yang diperoleh dari model regresi sebagai variabel dependen terhadap semua variabel independen dalam model regresi. Apabila nilai koefisien regresi dari masingmasing variabel bebas dalam model regresi ini tidak signifikan secara statistik, maka dapat disimpulkan tidak terjadi heteroskedastisitas (Ghozali, 2011). Hasil uji Glejser dapat dilihat dalam tabel berikut : 
Tabel 4.4 Uji Heteroskedastitas

\begin{tabular}{|c|c|c|c|c|c|}
\hline \multicolumn{6}{|c|}{ Coefficients $^{a}$} \\
\hline \multirow[b]{2}{*}{ Model } & \multicolumn{2}{|c|}{$\begin{array}{l}\text { Unstandardiz } \\
\text { ed } \\
\text { Coefficients }\end{array}$} & $\begin{array}{c}\text { Stan } \\
\text { dardi } \\
\text { zed } \\
\text { Coeff } \\
\text { icient } \\
\text { s }\end{array}$ & & \\
\hline & B & $\begin{array}{l}\text { Std. } \\
\text { Error }\end{array}$ & Beta & $\mathrm{t}$ & Sig. \\
\hline $\begin{array}{l}\text { (Constan } \\
\text { t) }\end{array}$ & .268 & .914 & & $\begin{array}{r}.29 \\
4\end{array}$ & .770 \\
\hline Motivasi & .035 & .241 & .088 & .143 & .886 \\
\hline
\end{tabular}

a. Dependent Variable: Abs_res

Karena nilai koefisien regresi dari masing-masing variabel bebas dalam model regresi nilai absolut residual ini tidak signifikan secara statistik ( $p$ > 0,05), maka dapat disimpulkan tidak terjadi heteroskedastisitas

4.1.5 Analisis Regersi

Analisis ini digunakan untuk menentukan suatu persamaan regresi yang dapat menunjukkan ada tidaknya pengaruh secara signifikan variabel bebas terhadap variabel terikat melalui persamaan regresi sebagai berikut.

Tabel 4.5 Uji t

\begin{tabular}{|c|c|c|c|c|c|}
\hline \multicolumn{6}{|c|}{ Coefficients } \\
\hline \multirow[b]{2}{*}{ Model } & \multicolumn{2}{|c|}{$\begin{array}{c}\text { Unstandardiz } \\
\text { ed } \\
\text { Coefficients }\end{array}$} & \multirow{2}{*}{$\begin{array}{c}\begin{array}{c}\text { Standar } \\
\text { dized } \\
\text { Coeffici } \\
\text { ents }\end{array} \\
\text { Beta }\end{array}$} & \multirow[b]{2}{*}{$\mathrm{t}$} & \multirow[b]{2}{*}{ Sig. } \\
\hline & B & $\begin{array}{l}\text { Std. } \\
\text { Error }\end{array}$ & & & \\
\hline $\begin{array}{ll}1 & \text { (Consta } \\
& \mathrm{nt})\end{array}$ & -1.232 & 1.448 & & -.851 & $\begin{array}{r}.39 \\
7\end{array}$ \\
\hline $\begin{array}{l}\text { Motivas } \\
\text { i }\end{array}$ & 1.046 & .382 & 1.115 & $\begin{array}{r}2.73 \\
8\end{array}$ & $\begin{array}{r}.00 \\
7\end{array}$ \\
\hline
\end{tabular}

a. Dependent Variable: Kinerja

Hasil Analisis Persamaan Regresi

Berdasarkan hasil analisis tersebut dapat disusun dalam persamaan regresi berikut ini:

$\mathrm{Y}=1,115 \mathrm{X}_{1}$

Dimana:

$\mathrm{Y}=$ Kinerja

$\mathrm{X}=$ Motivasi 


\subsubsection{Uji Kecocokan Model}

\section{Koefisien Determinasi (Adjusted R Square)}

Nilai Adjusted $R$ Square digunakan untuk mengetahui persentase variabel bebas secara simultan/bersama-sama dalam memberikan kontribusi variabel terikat. Berdasarkan nilai Adjusted $R$ Square ini dapat diketahui besarnya pengaruh variabel lain di luar model regresi (Ghozali, 2011). Nilai Adjusted $R$ Square pada persamaan regresi dalam penelitian ini adalah sebagai berikut :

Tabel 4.6 Uji Kecocokan Model

\begin{tabular}{|l|c|c|c|c|}
\multicolumn{5}{|c|}{ Model Summary } \\
\begin{tabular}{|l|c|c|} 
Mod \\
el
\end{tabular} & $\mathrm{R}$ & $\begin{array}{c}\text { Rquar } \\
\mathrm{e}\end{array}$ & $\begin{array}{c}\text { Adjusted } \\
\text { R Square }\end{array}$ & $\begin{array}{c}\text { Std. Error of } \\
\text { the Estimate }\end{array}$ \\
\hline 1 & $\begin{array}{r}.76 \\
5^{\mathrm{a}}\end{array}$ & .586 & .563 & .31880 \\
\hline
\end{tabular}

a. Predictors: (Constant), Interaksi motivasi

Nilai Adjusted R square sebesar 0,563 artinya 56.3\% variasi kinerja guru dapat dijelaskan oleh variabel motivasi kerja. Sedangkan sisanya sebesar $(100-56,3 \%)$ yaitu sebesar $43,7 \%$ dijelaskan oleh variabel lain diluar model penelitian.

Tabel 4.7 Uji Signifikansi Simultan (Uji F)

\begin{tabular}{|c|c|r|r|r|r|}
\hline \multicolumn{10}{|c|}{ ANOVA $^{\text {b }}$} & $\begin{array}{c}\text { Sum of } \\
\text { Square } \\
\text { Model }\end{array}$ & df & $\begin{array}{c}\text { Mean } \\
\text { Square }\end{array}$ & F & Sig. \\
\hline $1 \quad \begin{array}{l}\text { Regr } \\
\text { essio } \\
\mathrm{n}\end{array}$ & 13.087 & 5 & 2.617 & 25.754 & $\begin{array}{r}.00 \\
0^{\mathrm{a}}\end{array}$ \\
$\begin{array}{l}\text { Resid } \\
\text { ual } \\
\text { Total }\end{array}$ & 9.249 & 91 & .102 & & \\
\hline
\end{tabular}

a. Predictors: (Constant), Motivasi,

b. Dependent Variable: Kinerja

Uji Signifikansi Simultan (Uji Statistik F) ini digunakan untuk mengetahui pengaruh secara simultan (bersama-sama) antara semua variabel bebas terhadap variable terikat yaitu kinerja guru. Berdasarkan hasil uji $\mathrm{F}$ diperoleh nilai signifikansi sebesar 0,000 $<0,05$ berarti model diterima.

4.1.7 Uji Hipotesa

Uji $t$ digunakan untuk menguji dan menganalisis pengaruh signifikansi masing-masing variabel independen dan variabel moderating terhadap variabel dependen secara parsial. Jika nilai $t_{\text {hitung }}$ positif atau nilai signifikansi < 0,05 maka dapat dinyatakan bahwa hipotesis diterima, 
sehingga ada pengaruh signifikan antara variabel independen terhadap variabel dependen. Berdasarkan hasil uji t dalam tabel 4.14 diperoleh hasil sebagai berikut:

Uji pengaruh secara parsial antara motivasi kerja terhadap kinerja guru diperoleh beta 1,115 bertanda positif dan nilai 0,007 $<0,05$ maka $\mathrm{H}_{1}$ diterima yang berarti motivasi kerja berpengaruh positif dan signifikan terhadap kinerja guru.

\subsection{Pembahasan}

Hipotesis yang mengatakan bahwa motivasi kerja memiliki pengaruh positif dan signifikan terhadap kinerja guru dapat diterima dan terbukti benar dimana variabel motivasi kerja memiliki pengaruh positif terhadap kinerja artinya setiap terjadi peningkatan motivasi kerja pada RA di Kota Pekalongan akan meningkatkan kinerja guru.

Motivasi pada dasarnya dapat bersumber pada diri seseorang atau yang sering dikenal sebagai motivasi internal dan dapat pula bersumber dari luar diri seseorang atau disebut juga motivasi eksternal. Faktor-faktor motivasi tersebut dapat berdampak positif atau dapat pula berdampak negative bagi seorang guru. Dalam teori motivasi Herzberg, faktor-faktor motivator meliputi prestasi, pengakuan, tanggungjawab, kemajuan, pekerjaan itu sendiri dan kemungkinan berkembang.

Apabila pekerja mempunyai motivasi yang tinggi untuk mencapai tujuan pribadinya, maka mereka harus meningkatkan kinerja. Meningkatnya kinerja pekerja akan meningkat pula kinerja organisasi. Dengan demikian, meningkatkannya motivasi pekerja akan meningkatkan kinerja individu, kelompok, maupun organisasi sehingga dapat mencapi target organisasi yang telah ditetapkan.

Motivasi merupakan proses psikologis yang membangkitkan dan mengarahkan perilaku pada pencapaian tujuan atau goal-directed behavior (Kreitnen dan Kinicki, 2009). Manager dalam hal ini kepala sekolah perlu memahami proses psikologis, apabila mereka ingin berhasil membina pekerjaan guru guna menuju pada pencapaian target organisasi.

Guru diharapkan merupakan orang yang karena profesinya sanggup menimbulkan dan mengembangkan motivasi untuk kepentingan proses aspek-aspek pembelajaran di dalam kelas yang keberadaan siswanya berbedabeda secara individual, misalnya perbedaan minat, bakat, kebutuhan, kemampuan, latar belakang sosial dan konsep yang dipelajari. Dengan motivasi dari guru merupakan faktor yang berarti dalam pencapaian tujuan pembelajaran. Dua pembangkit motivasi belajar yang efektif adalah keingintahuan dan keyakinan dalam kemampuan diri para siswa . Setiap siswa memiliki rasa ingin tahu, maka guru perlu memotivasi dengan pertanyaan diluar kebiasaan atau pemberian tugas yang menantang disertai penguatan bahwa siswa mampu melakukannya.

\section{SIMPULAN DAN SARAN}

\subsection{Simpulan}

Berdasarkan hasil penelitian tersebut dapat diambil kesimpulan bahwa motivasi kerja berpengaruh positif dan signifikan terhadap kinerja guru RA di Kota Pekalongan. 


\subsection{Saran}

Saran dan rekomendasi dari penelitian ini adalah :

1. Bagi para Kepala Sekolah dan Guru RA Kota Pekalongan hendaknya terus meningkatkan motivasi kerja sehingga menghasilkan kinerja menjadi semakin baikdan optimal.

2. Bagi para pengambil kebijakan untuk sekolah RA Kota Pekalongan hendaknya meningkatkan kesejahteraan para Kepala Sekolah dan Guru guna mendorong meningaktnya motivasi kerja untuk menghasilkan kinerja yang otimal.

\section{DAFTAR PUSTAKA}

Ghozali Imam. 2011. Aplikasi Analisis Multivariate dengan Program SPSS. Semarang : Badan Penerbit Universitas Diponegoro

Hasibuan, Malayu S.P. 2014. Manajemen Sumber Daya Manusia. Jakarta: PT Bumi Aksara.

Ivancevich, Jhon M. Robert Konopaske. Michael T. Matteson. 2006. Perilaku dan Manajemen Organisasi. Jakarta. Erlangga.

Mangkunegara, A.A., Anwar P. 2009. Manajemen Sumber Daya Manusia Perusahaan. Bandung: PT. Remaja Rosdakarya

Prawirosentono, Suryadi. 1999. Kebijakan Kinerja Karyawan. Yogyakarta: BPFE

Robert Kreitner and Angelo Kinicki, Organizational Behavior (2009)

Yamin, Martinis dan Maisah. 2010. Standarisai Kinerja Guru. Jakarta: GaungPersada Press

Undang-Undang No.14 Tahun 2005 tentang Guru dan Dosen

Peraturan Pemerintah No.19 Tahun2005 tentang Standar Pendidikan Nasional

Undang-Undang Republik Indonesia Nomor 20 Tahun 2003 tentang Sistem Pendidikan Nasional, 